\title{
Elasmobranch bycatch in US West Coast groundfish fisheries
}

\author{
Jason E. Jannot ${ }^{1, *}$, Rhema Bjorkland ${ }^{1,2}$, Kayleigh A. Somers ${ }^{1}$, Toby Mitchell ${ }^{1}$, \\ Vanessa J. Tuttle ${ }^{1}$, Jon McVeigh ${ }^{1}$
}

\author{
${ }^{1}$ Fisheries Resource Analysis and Monitoring Division, Northwest Fisheries Science Center, \\ National Marine Fisheries Service, NOAA, Seattle, WA 98112, USA \\ ${ }^{2}$ George Mason University, Department of Environmental Science and Policy, Fairfax, VA 22030, USA
}

\begin{abstract}
Effective management of multispecies fisheries in large marine ecosystems is challenging. To deal with these challenges, fisheries managers are moving toward ecosystem-based fishery management (EBFM). Despite this shift, many species remain outside protective legislation or fishery management plans. How do species that fall outside of formal management structures respond to changes in fisheries management strategies? In 2011, the US West Coast Groundfish Fishery (WCGF) shifted management to an Individual Fishing Quota (IFQ) program. We used data collected by fisheries observers to examine the impact of this shift on elasmobranch catch (sharks, skates, rays). Historically, not all elasmobranchs were included in the WCGF Management Plan, making them vulnerable to fishing mortality. We grouped elasmobranchs into 8 groups based on 14 ecomorphotypes to examine relative catch within groundfish fishing sectors during the period 2002-2014. Of the 22 sharks and 18 skates and rays that these fisheries capture, 9 are listed as Near Threatened or greater on the IUCN Red List and 10 species are listed as Data Deficient by IUCN. The bycatch of 4 non-managed elasmobranch species was reduced under the IFQ program; IFQ management had no significant impact on the remaining 27 species caught by the IFQ fleet. Overall, catch of non-managed elasmobranchs was relatively low. We show that groups of ecomorphotypes co-occur within fisheries, suggesting natural management units for use in EBFM. This work helps identify gaps in monitoring and assessing the impact of management and policy on elasmobranch populations.
\end{abstract}

KEY WORDS: Fishing mortality · Individual fishing quota - Sharks · Fisheries management · Ecomorphotype $\cdot$ Discards

\section{INTRODUCTION}

In the last $20 \mathrm{yr}$, fisheries science has moved away from single-species approaches to management toward ecosystem-based fisheries management (EBFM), which incorporates ecological processes and components that have historically been left out of fisheries management (Link 2002, 2010, Latour et al. 2003). EBFM fosters a greater consideration of all components of marine ecosystems affected by fishing activity, including non-target species and associated habitats.

*Corresponding author: jason.jannot@noaa.gov
An on-going challenge of sustainable EBFM is the incidental catch of non-target species, or bycatch. Over-exploitation via fisheries bycatch has caused declines in several groups of marine organisms, including marine mammals, fishes, sea turtles, and invertebrates (Alverson et al. 1994, Dayton et al. 1995, Kelleher 2005, Dulvy et al. 2014). Evidence collected in recent years indicates that elasmobranchs (sharks, skates, rays) might be particularly susceptible to over-harvesting and bycatch in marine fisheries (Dulvy et al. 2014, Oliver et al. 2015, James

(C) R. Bjorkland and, outside the USA, the US Government 2021. Open Access under Creative Commons by Attribution Licence. Use, distribution and reproduction are unrestricted. Authors and original publication must be credited.

Publisher: Inter-Research · www.int-res.com 
et al. 2016). Elasmobranchs are relatively long-lived vertebrates, with low biological productivity, a product of life history characteristics (e.g. slow growth, late age maturity, extended longevity; Stevens et al. 2000, Cortés 2002) that make them vulnerable to declines and extinctions when fishing-induced mortality rises in the absence of management (Dulvy et al. 2014, Oliver et al. 2015, James et al. 2016). Loss of species from marine systems, including elasmobranchs, can have serious consequences. For example, there is evidence that depletion of top predators such as sharks can have cascading effects throughout the marine ecosystem (Stevens et al. 2000, Baum \& Worm 2009, Block et al. 2011). Recent estimates indicate that global shark removals may be in the tens of millions of individuals annually (Clarke et al. 2006, Crowder et al. 2008, Oliver et al. 2015, James et al. 2016). Stevens et al. (2000) estimated that almost $50 \%$ of global chondrichthyan catch (elasmobranchs and chimaeras) was non-targeted bycatch.

Retention of incidentally caught elasmobranchs is on the rise for a variety of reasons, with little management oversight (Oliver et al. 2015, James et al. 2016). New markets and demand can drive the retention of incidental elasmobranch catches (Walker 1998, Fong \& Anderson 2002) as traditional target species decline (Ward-Paige et al. 2012, Dulvy et al. 2014), resulting in unregulated removals of elasmobranchs (Davies et al. 2009, James et al. 2016). Nontargeted and unmanaged catch can negatively affect elasmobranch populations if mortality for these species goes undocumented and is above maximum sustainable yield (Oliver et al. 2015). Changes in fisheries management provide an opportunity to examine the impact of management on unregulated species such as elasmobranchs.

In 2011, one of the largest segments (a.k.a. sector) of the US West Coast Groundfish Fishery (WCGF) underwent a shift in fisheries management. The WCGF operates along the US Pacific Coast from the Washington-Canada border to the California-Mexico border. Until 2011, the WCGF Limited Entry Bottom Trawl sector fished for groundfish species under a fisherywide annual catch limit. Fishers could fish and retain up to a limited amount, but were not penalized for discards above the limit. In 2011, management of this sector changed to an Individual Fishing Quota (IFQ) system. IFQ management requires fishers to hold quota for every pound of fish caught, for approximately 70 of the 94 species managed by the Pacific Fishery Management Council (PFMC) West Coast Groundfish Fishery Management Plan (WCGFMP). To ensure compliance, the IFQ program requires dis- card monitoring of $100 \%$ of the fishing trips because both retained and discarded catch are debited against individual's quota. The WCGFMP includes 4 species of elasmobranchs that are actively managed (i.e. defined catch limits): leopard Triakis semifasciata and spiny dogfish Squalus suckleyi sharks, and longnose Raja rhina and big $R$. binoculata skates (see Tables 3-1 in PFMC 2019). The PFMC also monitors, but does not actively manage, a number of skates designated as Ecosystem Component Species (ECS) in the WCGFMP, including Aleutian Bathyraja aleutica, Bering $B$. interrupta, sandpaper $B$. kincaidii, roughtail/black $B$. trachura, and all other endemic skates. California skate $R$. inornata, soupfin shark Galeorhinus galeus, and spotted ratfish Hydrolagus colliei are also currently monitored as ECS; however, during the time period covered in the present study (2002-2014), these 3 species were managed within the WCGFMP, thus we excluded them from our analysis. All other species of sharks, skates, and rays along the US West Coast were outside the umbrella of active management in the WCGFMP during this time period. It should be noted that the PFMC's Highly Migratory Species (HMS) FMP does monitor a number of elasmobranch species not covered by the WCGFMP and that other management agencies and voluntary measures have been adopted by state and tribal agencies to protect some of these elasmobranchs. Our focus here was to assess the impacts of management changes to the WCGFMP on incidental catch of elasmobranchs in fisheries managed by the WCGFMP.

In this study, we tested the hypothesis that the implementation of the IFQ program has reduced the catch of elasmobranchs not actively managed by the WCGFMP (PFMC 2019). IFQ programs incentivize fishers to use resources prudently and fish more efficiently (Branch 2009, Melnychuck et al. 2012). If true, IFQ programs could indirectly reduce the catch of non-quota elasmobranchs in at least 2 ways. First, as fishers approach and eventually attain individual species quotas, fishing effort likely declines, resulting in a reduction in per vessel catch of all species, including non-target elasmobranchs. Second, efficient fishers will be more selective, which might reduce bycatch of unmanaged species. Fishers must carry enough quota to cover their total catch (at-sea discards and dockside landings) for each species within the IFQ program. Fishers should maximize efficient fishing by avoiding species that will cause them to exceed their individual quota for that species (a.k.a. constraining species). Once an individual fisher's quota for a constraining species has been attained, any further catch of that species can incur 
economic costs of finding more quota on the open market or forgo fishing for the remainder of the season. Thus, constraining species changes fisher behavior by either inducing more selective fishing or reducing effort.

To place our results in the context of global elasmobranch bycatch, we also describe the diversity of elasmobranchs that interact with the WCGF and identify species of concern, estimate incidental catch on those elasmobranch species not actively managed by the current WCGFMP (PFMC 2019), and examine trends in non-managed elasmobranch catch across time and fishery sectors. Even though most elasmobranchs are not part of the IFQ program, these species could exhibit reduced catch under the IFQ program as an indirect effect of more efficient fishing in the IFQ program. Alternatively, non-managed elasmobranch catch could increase under the IFQ program because there are no incentives (i.e. no quota) to reduce non-managed elasmobranch catch per se. Therefore, these species could be discarded at sea or retained and sold to exploit or develop new markets, without penalty. A third possibility is that overall elasmobranch catch does not change, but the proportion of at-sea discards and landings changes for individual species. We would expect this result if, for example, fishers found or developed new markets for unregulated elasmobranchs. We highlight elasmobranch species that are of regional or global conservation concern and which fall outside active management in the WCGFMP. We use these species as an example of the effect of fisheries management on unmanaged species. In addition, our results provide recommendations for improving elasmobranch management in the WCGF as well as around the globe.

\section{METHODS}

\subsection{Federally managed fisheries}

The PFMC regulates federally managed fisheries in the WCGF, based on access privileges and gear types. The PFMC, in consultation with state agencies (Washington, Oregon, and California), also sets some fishing regulations for state-managed fisheries that interact with groundfish species listed in the WCGFMP. Access privileges in US federally managed fisheries are either Limited Entry (LE), Open Access (OA), IFQs, or cooperatives that pool and share quota in the IFQ program. A federal groundfish permit is required to participate in the LE fisheries, but not required in the OA fisheries, with LE fishers having access to greater amounts of fishery resources than OA fishers. The permits, gear types, target species, vessel lengths, fishing depths, and management for each sector of the WCGF during the study period (2002-2014) are described in Texts S1 \& S2 and Table S1 in the Supplement at www.int-res.com/ articles/suppl/n045p109_supp.pdf.

Historically, there were 3 main federal sectors, defined by gear type and target species: LE Bottom Trawl, At-sea and Shoreside Hake (pelagic trawl), and Non-Nearshore Fixed Gear (hook-and-line or pot gears; Table S1). From 2002-2010, management of the LE Bottom Trawl sector included a number of measures designed to maintain catches below prescribed TACs (total allowable catches), including the establishment of conservation areas closed to bottom trawling as well as trip and bi-monthly caps on landings of several species (Table S1). However, fishers could continue to fish until they had reached the maximum landing allowance for each species, discarding at will. In January 2011, management of the LE Bottom Trawl fishery changed to an IFQ system. Individual permit holders can fish, lease, or sell their individual quota. Under IFQ, the scope of allowable gear types was broadened (Table S1). IFQ fishers hold quota for both target (intended catch) and nontarget (unintended catch) species and species groups, and both discarded and retained catch debits against individual quota accounts. When a fisher fills their individual quota for a particular species, they cannot catch any additional individuals of that species/group without potentially negative consequences, regardless if they are discarded or landed (NMFS 2010). Since 2011, the PFMC manages non-IFQ species contained in the WCGFMP under trip limits for landings, but at-will discarding is allowed. No management limits were set for species outside the WCGFMP, including non-managed elasmobranchs, during the study period (2002-2014). For the purposes of clarity, in this paper we refer to the 2002-2010 fishery period as the LE Bottom Trawl sector and the 2011-2014 fishery period as the Non-Hake IFQ sector. The LE Trawl-IFQ sector is the focus of this paper, though we compared this fishery to other fishery sectors off the US west coast. These other federal and state fisheries are described in detail in Texts S1 \& S2 and Table S1.

\subsection{Data}

We assessed the impact of US West Coast fisheries that target groundfish or incidentally catch groundfish on elasmobranchs by estimating total catch- 
both discards at sea and catch landed at the dock - of each non-managed elasmobranch species for the time period 2002-2014. For simplicity, we refer to the collection of fisheries as the WCGF, even though some of these fisheries only catch groundfish incidentally. We used 3 data sources for this study: at-sea discard data from the Northwest Fisheries Science Center Groundfish Observer Program (NWGOP), federal logbook data, and landed data, both from the Pacific Fisheries Information Network (PacFIN). At-sea discard data (e.g. individuals caught but not landed/retained) from each sector was collected by independent scientific observers placed on commercial fishing vessels by the NWGOP during fishing operations. Collection of discard data has been required on every IFQ Non-Hake and Shoreside Hake fishery trip since 2011 to ensure IFQ program compliance such that $100 \%$ of trips have been monitored. Similarly, At-sea Hake Catcher Processors and At-sea Hake Motherships had $100 \%$ observer coverage for the 2002-2014 period. All other fishery sectors had less than 100\% observer coverage (Somers et al. 2018a). In those sectors with less than $100 \%$ observer coverage (see Table S1), observed elasmobranch catch must be expanded to the unobserved portion of the fleet. NWGOP observers collect the following information for each fishing event (a.k.a. a set or a haul): latitude, longitude, date, and time and geolocation of gear placement and retrieval; average fishing depth; the intended target group or species (as indicated by the captain or other crew member); and at-sea catch including at-sea discards. Details of NWGOP observer duties, priorities, and sampling protocols can be found in the NWGOP Manuals (NWFSC 2016a,b,c).

Vessel logbook data, only available for the LE Bottom Trawl sector, were obtained from PacFIN (see Fig. 1 in Bellman et al. 2011). Trawl logbook tows lacking a recorded depth $(0.18 \%)$ were removed to ensure that all spatial and depth information was complete. Landed catch for all fishing sectors was obtained from fish tickets-trip-aggregated sales receipts issued to vessels by fish-buyers in each port for each delivery of fish and electronically reported by each state to PacFIN. Details of NWGOP data quality control, processing, and matching of discards, logbook, and landings can be found on the NWGOP website (NWFSC 2020a,b).

\subsection{Discard and catch estimates}

Observer estimates of at-sea discards from sampling each haul were expanded to the haul level (for details see NWFSC 2020a). Haul-level at-sea discard estimates were then expanded to the sector-level for sectors with less than 100\% observer coverage (LE Bottom Trawl 2002-2010, LE Sablefish, LE Fixed Gear Daily Trip Limits [DTL], OA Fixed Gear, OA California Halibut, Nearshore, Pink Shrimp). Sector expansion was not required in the Non-Hake IFQ (20112014), Shoreside Hake, At-sea Catcher Processor, and At-sea Mothership Catcher Vessel sectors because $100 \%$ observer coverage is mandatory in these sectors. A small number of IFQ hauls go unsampled each year (typically <1 \%; Somers et al. 2018a).

For sectors with less than $100 \%$ observer coverage, discard ratios were computed from the observer data as the ratio of observed discard of a single species to the observed retained of target species in that sector (see Somers et al. 2015 for full description). Discard ratios were then used to expand discarded weight of each species from the sampled to the unsampled portion of the catch to give $\hat{D}$, the discard estimate:

$$
\hat{D}_{S X}=\frac{\sum_{t} d_{s X t}}{\sum_{t} r_{X t}} \times \sum_{t} R_{X t}
$$

where $s$ is the species or species group, $x$ is the sector, $t$ is tows, $d$ is the observed discard weight of species $S, r$ is the observed retained weight of target species in sector $x$, and $R$ is the total weight of retained target species in sector $x$. Retained catch in sectors were obtained from fish tickets. Fish tickets contain weight estimates of species or species groups brought back to the dock and are required for fish sales in the WCGF. However, fish tickets do not record measures of effort such as the number of hauls, gear deployments, or fishing durations. Thus, fish ticket weights represent our only measure of fleetwide effort. Data on fish tickets is often reported as a market category, encompassing multiple species, e.g. 'skate unidentified'. Furthermore, non-managed elasmobranch species are not required to be sorted at the dock and identified to species, and in many instances might be discarded at the dock without ever being recorded on the fish ticket (i.e. unmarketable species; PFMC 2019). Therefore, estimates of landed elasmobranchs in this study likely underrepresent the true amount of non-managed elasmobranchs actually brought back to the docks. The non-managed elasmobranchs in this study are not the target of any of these fisheries. We use the term 'landed' to indicate non-elasmobranch catch brought back to the dock, as opposed to discarded at sea. We reserve the term 'retained' for catch of managed species that are subsequently sold to a fish buyer at the dock. 
In the At-sea Hake sectors, each vessel carries 2 observers, therefore nearly $100 \%$ of the hauls are sampled for species composition. The expansion factors for unsampled hauls in the At-sea Hake sectors are very small. At the species level, At-sea Hake observers estimate a percent retained for each haul, based on what they observe. This estimate is applied to the total catch weight of the species. At the haul level, observers also calculate a total discard weight for the haul by using the bycatch totals and the percent retained estimates to get the total discard for the haul (all species).

Total catch for each elasmobranch species was calculated by summing the discard (estimated from observer data and fish tickets, see above) and landed estimates (from fish tickets) across all tows and trips for each year-sector-species. We used the landings weight on fish tickets as a proxy for effort. The weight of total landings represents our best measure of the effort for a particular sector in a given year. We calculated total landings across sectors by summing the weight of all species on the fish tickets (landed and retained; including elasmobranchs). To make comparisons among sectors and gear types, we scaled total elasmobranch catch by total landings, our proxy for effort, resulting in relative catch of elasmobranch species for a given year $(\mathrm{mt} / \mathrm{mt})$. Relative catch was calculated as the total catch of an elasmobranch species within a sector (see above) divided by the total landings across all sectors (above). Relative catch weight can be thought of as 'catch-per-uniteffort' and provides a standardized metric that can be compared across sectors that have very different target species and gear types. A similar approach was taken by Oliver et al. (2015) in their estimates of global elasmobranch bycatch in commercial longline, trawl, purse seine and gillnet fisheries. For the elasmobranch species in this study, we assume 100\% mortality of all individuals from all fisheries because fishing-induced mortality rates for these species have not been determined. Thus, our estimates are conservative and should be considered near the upper bound of mortality in these fisheries since some individuals of some species are likely to survive capture after being discarded at sea.

We classified elasmobranchs into groups based on ecomorphotypes (Table 1) that reflect broad habitat preferences, bathymetric distribution, and feeding ecology. Shark ecomorphotype categories were based on Compagno (1990) and Martin (2010). The data summed at the ecomorphotype level was too sparse (many zeros) for modeling purposes. Therefore, we further combined ecomorphotypes into more general habitat categories (Table 1). The shark ecomorphotypes were grouped into coastal sharks, slope sharks, deep slope sharks, and oceanic sharks. Skate and ray ecomorphotypes were grouped into nearshore, shelf/slope, deep water, and pelagic (Fowler et al. 2005, IUCN 2020). Relative catch was then calculated (see above) for both sharks and skates within each of their respective groupings (Table 1).

\subsection{Modeling and analyses}

To examine the impact of the IFQ program on elasmobranchs, we used a generalized linear model (GLM) to examine the effect of fishery sector (12 sectors; Table S1), time periods (2002-2006, 2007-2010, 2011-2014), and grouping (8 groups; Table 1) on relative catch. To test for an effect of IFQ implementation on elasmobranch relative catch, the data were grouped into 3 time periods: 2002-2006, 2007-2010, and 2011-2014. These periods were chosen because the 2011-2014 period represents the period when the IFQ program was active. The other periods were chosen to have roughly the equivalent number of years while still using all available data. A significant decline in mean predicted relative catch from the 2007-2010 to the 2011-2014 period would lend support to the idea that the IFQ program reduced the catch of elasmobranchs.

To examine the effects of fishery sector on IUCNlisted species (Table 2), we used GLMs to test the impact of sector on relative catch of the subset of IUCNlisted species. We modeled the effect of sector on IUCN species for 3 habitats: oceanic, which included the oceanic sharks; slope, which included deep slope sharks, slope sharks, and slope skates; and nearshore, which included coastal sharks and nearshore skates and rays. For each habitat, we examined the effect of sector on the IUCN species found in that habitat. We limited each of the 3 analyses to only those sectors that had some catch of at least one IUCN species. The oceanic habitat analysis included all sectors, the slope habitat analysis excluded the Nearshore and Shoreside Hake sectors and the nearshore habitat analysis excluded At-sea Catcher Processors, LE Fixed Gear DTL, LE Sablefish, Pink Shrimp, and Shoreside Hake.

To examine the impact of the IFQ program on elasmobranchs within the LE Trawl-IFQ sector, we used a GLM to examine the effect of species (excluding any groups not identified to species), time period, and catch disposition (at-sea discard vs. landed at dock) on total catch of elasmobranchs (by weight, mt) within the LE Trawl-IFQ sector. Including catch dis- 
Table 1. Shark, ray, and skate species observed in the US West Coast groundfish fishery, grouped by ecomorphotype. Shark ecomorphotypes based on Martin's (2010) revision of Compagno (1990). Compagno (1990) ecomorphotypes are given in brackets if different from Martin (2010). Skates and ray ecomorphotypes based on the biology and habitat of individual species. B: benthic/epibenthic; CI: coastal and insular; H: continental shelf and upper slope; L: littoral; O: open ocean; p: pelagic; S: continental slope; SI: continental and insular slope; CA: California

\begin{tabular}{|c|c|c|c|c|c|}
\hline Grouping & Ecomorphotype & Species & Scientific name & Family & Habitat \\
\hline \multirow[t]{7}{*}{ Coastal sharks } & Cancritrophic & Brown smoothhound & Mustelus henlei & Triakidae & $\mathrm{L}, \mathrm{CI}$ \\
\hline & & Gray smoothhound & Mustelus californicus & Triakidae & L \\
\hline & $\begin{array}{l}\text { Cancritrophic } \\
\text { (probenthic) }\end{array}$ & Swell & $\begin{array}{c}\text { Cephaloscyllium } \\
\text { ventriosum }\end{array}$ & Scyliorhindae & L, CI \\
\hline & $\begin{array}{l}\text { Durotrophic } \\
\text { (probenthic) }\end{array}$ & Horn & Heterodontus francisci & Heterodontidae & $\mathrm{CI}$ \\
\hline & Eurytrophic & Broadnose sevengill & Notorynchus cepedianus & Notorynchidae & $\mathrm{L} ; \mathrm{CI}$ \\
\hline & Mesotrophic (littoral) & Pacific sharpnose & Rhizoprionodon longurio & Carcharhinidae & L \\
\hline & $\begin{array}{c}\text { Platybenthic } \\
\text { (squatinobenthic) }\end{array}$ & Pacific angel shark & Squatina californica & Squatinidae & $\mathrm{L} ; \mathrm{CI}$ \\
\hline \multirow[t]{5}{*}{ Deep sea skates } & Deep water skates & Black skate & Bathyraja trachura & Arhynchobatidae & $\mathrm{S}$ \\
\hline & & Bering skate & Bathyraja interrupta & Arhynchobatidae & $\mathrm{S}$ \\
\hline & & Deepsea skate & Bathyraja abyssicola & Arhynchobatidae & $\mathrm{S}$ \\
\hline & & White skate & Bathyraja spinosissima & Arhynchobatidae & $\mathrm{S}$ \\
\hline & & Broad skate & Amblyraja badia & Rajidae & $\mathrm{S}$ \\
\hline \multirow{4}{*}{$\begin{array}{l}\text { Deep slope } \\
\text { sharks }\end{array}$} & Mesobathic & Pacific black dogfish & Centroscyllium nigrum & Etmopteridae & SI \\
\hline & (bathic) & Prickly shark & Echinorhinus cookei & Echinorhinidae & SI \\
\hline & Mesobathic & Pacific sleeper shark & Somniosus pacificus & Somniosidae & SI \\
\hline & (eurytrophic) & Bluntnose sixgill shark & Hexanchus griseus & Hexanchidae & SI \\
\hline \multirow{9}{*}{$\begin{array}{l}\text { Nearshore } \\
\text { skates and } \\
\text { rays }\end{array}$} & Nearshore rays & Banded guitarfish & Zapteryx exasperata & Rhinobatidae & $\mathrm{B}$ \\
\hline & & Bat ray & Myliobatis californica & Myliobatidae & $\mathrm{B}$ \\
\hline & & Ca butterfly ray & Gymnura marmorata & Gymnuridae & $\mathrm{B}$ \\
\hline & & Diamond stingray & Dasyatis dipterura & Dasyatidae & B \\
\hline & & Pacific electric ray & Tetronarce californica & Torpedinidae & $\mathrm{B}$ \\
\hline & & Round stingray & Urobatis halleri & Urolophidae & $\mathrm{B}$ \\
\hline & & Starry skate & Raja stellulata & Rajidae & $\mathrm{B}$ \\
\hline & & Shovelnose guitarfish & Rhinobatos productus & Rhinobatidae & $\mathrm{B}$ \\
\hline & & Thornback guitarfish & Platyrhinoidis triseriata & Platyrhinidae & B \\
\hline \multirow[t]{6}{*}{ Oceanic sharks } & Macropelagic & Bigeye thresher & Alopias superciliosus & Alopiidae & $\mathrm{O}$ \\
\hline & (macroceanic) & Blue shark & Prionace glauca & Carcharhinidae & $\mathrm{O}$ \\
\hline & & Common thresher & Alopias vulpinus & Alopiidae & $\mathrm{O}$ \\
\hline & & Pelagic thresher & Alopias pelagicus & Alopiidae & $\mathrm{O}$ \\
\hline & Tachypelagic & Shortfin mako & Isurus oxyrinchus & Lamnidae & $\mathrm{O}$ \\
\hline & & Salmon shark & Lamna ditropis & Lamnidae & $\mathrm{O}$ \\
\hline Pelagic ray & Pelagic rays & Pelagic stingray & Pteroplatytrygon violacea & Dasyatidae & $\mathrm{P}$ \\
\hline \multirow[t]{3}{*}{ Slope sharks } & Anoxybathic & Filetail cat shark & Parmaturus xaniurus & Scyliorhinidae & SI \\
\hline & $\begin{array}{l}\text { Cyranobathic } \\
\text { (rhynchobatic) }\end{array}$ & Brown cat shark & Apristurus brunneus & Scyliorhinidae & SI \\
\hline & Cyranobathic & Longnose cat shark & Apristurus kampae & Scyliorhinidae & SI \\
\hline \multirow[t]{3}{*}{ Slope skates } & Shelf/slope skates & Aleutian skate & Bathyraja aleutica & Arhynchobatidae & H; deeper than 200 m \\
\hline & & Sandpaper skate & Bathyraja kincaidii & Arhynchobatidae & $\mathrm{H}_{\text {; }}$ deeper than $200 \mathrm{~m}$ \\
\hline & & Starry skate & Raja stellulata & Rajidae & $\mathrm{H}_{\text {; }}$ shallower than $200 \mathrm{~m}$ \\
\hline
\end{tabular}

position and species in these models allowed us to assess the potential for species-specific shifting uses of bycatch. For example, if new markets were being exploited or developed for certain non-quota elasmobranchs, we would expect landings to rise even as discards at-sea fell. Because a large portion of sharks, skates, and rays were unidentified, we also fit a sep- arate GLM to the unidentified sharks, skates, and rays to examine the effect of group (unidentified shark vs. skates and rays), catch disposition (at-sea discard vs. landed at dock), and time period on total catch (weight, mt) of these unidentified groups. Any group not identified to species was included in the 'unidentified' analysis (see Tables $3 \& 4$ ). 
Table 2. Shark, skate and ray species observed in the US West Coast groundfish fishery with an IUCN Red List status greater than Least Concern or listed as Data Deficient (IUCN 2020)

\begin{tabular}{|lcccc|}
\hline Common name & Scientific name & Population trend & IUCN status & Ecomorphotype \\
\hline Pelagic thresher shark & Alopias pelagicus & Declining & Endangered & Oceanic shark \\
Shortfin mako shark & Isurus oxyrinchus & Declining & Endangered & Oceanic shark \\
Bigeye thresher shark & Alopias superciliosus & Declining & Vulnerable & Oceanic shark \\
Common thresher shark & Alopias vulpinus & Declining & Vulnerable & Oceanic shark \\
Blue shark & Prionace glauca & Declining & Near Threatened & Oceanic shark \\
Bluntnose sixgill shark & Hexanchus griseus & Unknown & Near Threatened & Deep slope shark \\
Broadnose sevengill shark ${ }^{a}$ & Notorynchus cepedianus & Unknown & Near Threatened & Coastal shark \\
Pacific angel shark & Squatina californica & Declining & Near Threatened & Coastal shark \\
Horn shark & Heterodontus francisci & Unknown & Data Deficient & Coastal shark \\
Longnose cat shark & Apristurus kampae & Unknown & Data Deficient & Slope shark \\
Pacific black dogfish & Centroscyllium nigrum & Unknown & Data Deficient & Deep slope shark \\
Pacific sharpnose shark & Rhizoprionodon longurio & Unknown & Data Deficient & Coastal shark \\
Pacific sleeper shark & Somniosus pacificus & Unknown & Data Deficient & Deep slope shark \\
Prickly shark & Echinorhinus cookei & Unknown & Data Deficient & Deep slope shark \\
Shovelnose guitarfish & Rhinobatos productus & Unknown & Near Threatened & Nearshore \\
Banded guitarfish & Zapteryx exasperata & Unknown & Data Deficient & Nearshore \\
Deepsea skate & Bathyraja abyssicola & Unknown & Data Deficient & Deep sea skate \\
Diamond stingray & Dasyatis dipterurus & Unknown & Data Deficient & Nearshore \\
Sandpaper skate & Bathyraja kincaidii & Unknown & Data Deficient & Slope skate \\
aEast Pacific subpopulation & & & & \\
& & & &
\end{tabular}

For all models, all possible interactions were added to the model to examine how factors interact (e.g. sector $\times$ period) to influence relative or total catch. Non-significant interactions were removed systematically starting with the highest order non-significant interactions. All interactions and main effects of lower order than the order being examined were kept in subsequent model runs. We used Akaike's information criterion (AIC) to assess the relative quality of alternative models (Tables S2 \& S4). For the sector by ecomorphotype by time period comparison, we present the model metrics and plot the predicted mean relative catch $( \pm 95 \% \mathrm{CI})$ from the final model by ecomorphotype for each sector as well as by the 3 time periods by sector. For the comparison of IUCN species by sector, we plot the predicted mean relative catch $( \pm 95 \% \mathrm{CI})$ for each species by sector for each of the 3 habitats. Finally, for the LE Trawl-IFQ analysis, we present the predicted mean weight of catch $( \pm 95 \% \mathrm{CI}$, in $\mathrm{mt})$ of at-sea discards and landed at the dock with sharks and skates and rays plotted separately. We used a normal error distribution for all models. $Q-Q$ plots indicated approximately normal distribution with slightly heavy tails for all models. Residual plots indicated either homoscedasticity or only slight heteroscedasticity, depending on the model. We explored time-series analyses (autoregressive integrated moving averages; ARIMAs) to examine the specific effect of year, but they added little to the results, interpretation, or conclusions; given the added complexity, we opted for the simpler models with fixed time periods. Modeling was conducted using R v.3.6.0 (R Core Team 2019), predicted values were obtained using the default settings of the 'effect' function of the R package 'effects', which averages over levels of each (non-focal) factor in the model and weighs levels of the factor in proportion to sample size (Fox 2003, Fox \& Weisberg 2018, 2019).

\section{RESULTS}

\subsection{Composition and species of conservation concern}

WCGF non-managed elasmobranch bycatch belonged to 14 ecomorphotypes and 8 broad groups (Table 1). Non-managed elasmobranch discards in WCGF fisheries included 20 species of sharks and 3 shark categories not identified to the species level (unidentified cat [Scyliorhinidae] and smoothhound [Mustelus] sharks; unidentified shark [of any type; Selachimorpha]; Table 3). In addition, there were 18 species of skates, rays, and guitarfish and 2 categories not identified to species (unidentified skates [Rajidae and Arhynchobatidae]; unidentified rays [Batoidea]; Table 4). Boxplots of total catch by species are shown in Fig. 1. The assemblage includes 9 species of concern: 3 Endangered (EN) species of shark, 4 shark and 1 guitarfish Near Threatened 
Table 3. Estimated weight of at-sea discards, landed at the dock, and total catch of sharks in the US West Coast groundfish fishery from 2002-2014. Ecomorphotypes are described in Table 1. Based on IUCN (2020): EN: Endangered, NT: Near Threatened; VU: Vulnerable; DD: Data Deficient; unid.: unidentified. Rounding might produce values that appear to equal zero

\begin{tabular}{|c|c|c|c|c|}
\hline Species & Ecomorphotype grouping & At-sea discards (mt) & Landed at dock (mt) & Total catch (mt) \\
\hline Blue - NT & Oceanic & 452.55 & 4.18 & 456.73 \\
\hline Salmon & Oceanic & 30.90 & 0.45 & 31.35 \\
\hline Common thresher - VU & Oceanic & 7.91 & 10.59 & 18.51 \\
\hline Shortfin Mako — EN & Oceanic & 1.21 & 11.01 & 12.22 \\
\hline Pelagic thresher - EN & Oceanic & 11.10 & 0.04 & 11.14 \\
\hline Bigeye thresher - EN & Oceanic & 0.00 & 0.06 & 0.06 \\
\hline Pacific sleeper - DD & Deep slope & 212.46 & 1.59 & 214.06 \\
\hline Pacific black dogfish - DD & Deep slope & 6.27 & 0.00 & 6.27 \\
\hline Bluntnose sixgill —NT & Deep slope & 5.61 & 0.01 & 5.62 \\
\hline Prickly - DD & Deep slope & 0.02 & 0.00 & 0.02 \\
\hline Brown cat & Slope & 896.08 & 129.57 & 1025.65 \\
\hline Filetail cat & Slope & 114.25 & 0.00 & 114.25 \\
\hline Longnose cat-DD & Slope & 31.48 & 0.00 & 31.48 \\
\hline Cat unid. & Slope & 19.71 & 0.00 & 19.71 \\
\hline Brown smoothhound & Coastal & 98.03 & 0.00 & 98.03 \\
\hline Pacific angel —NT & Coastal & 17.93 & 9.72 & 27.65 \\
\hline Swell & Coastal & 21.48 & 0.00 & 21.48 \\
\hline Broadnose sevengill — NT & Coastal & 1.58 & 0.00 & 1.58 \\
\hline Smoothhound unid. & Coastal & 0.95 & 0.00 & 0.95 \\
\hline Horn - DD & Coastal & 0.20 & 0.00 & 0.20 \\
\hline Gray smoothhound & Coastal & 0.03 & 0.00 & 0.03 \\
\hline Pacific sharpnose-DD & Coastal & 0.03 & 0.00 & 0.03 \\
\hline Shark unid. & Unknown & 1157.39 & 50.72 & 1208.11 \\
\hline
\end{tabular}

Table 4. Estimated weight of at-sea discards, landed at the dock, and total catch of skates and rays in the US West Coast groundfish fishery from 2002-2014. Ecomorphotypes are described in Table 1. Based on IUCN (2020): NT: Near Threatened; DD: Data Deficient; unid.: unidentified. Rounding might produce values that appear to equal zero

\begin{tabular}{|c|c|c|c|c|}
\hline Species & Ecomorphotype grouping & At-sea discards (mt) & Landed at dock (mt) & Total catch (mt) \\
\hline Black skate & Deep sea & 433.52 & 0.31 & 433.83 \\
\hline Deepsea skate-DD & Deep sea & 9.96 & 0.00 & 9.96 \\
\hline White skate & Deep sea & 1.02 & 0.00 & 1.02 \\
\hline Roughshoulder/broad skate & Deep sea & 0.04 & 0.00 & 0.04 \\
\hline Bering skate & Deep sea & 0.04 & 0.00 & 0.04 \\
\hline Sandpaper skate-DD & Slope & 761.09 & 0.91 & 762.00 \\
\hline Aleutian skate & Slope & 23.12 & 0.00 & 23.12 \\
\hline Starry skate & Slope & 18.66 & 0.00 & 18.66 \\
\hline Alaska skate & Slope & 0.06 & 0.00 & 0.06 \\
\hline Bat ray & Nearshore & 381.70 & 0.65 & 382.36 \\
\hline Pacific electric ray & Nearshore & 96.64 & 0.04 & 96.68 \\
\hline Shovelnose guitarfish $-\mathrm{NT}$ & Nearshore & 20.07 & 0.00 & 20.07 \\
\hline Thornback guitarfish & Nearshore & 11.79 & 0.00 & 11.79 \\
\hline Pelagic stingray & Nearshore & 0.69 & 0.00 & 0.69 \\
\hline Round stingray & Nearshore & 0.39 & 0.00 & 0.39 \\
\hline Diamond stingray - DD & Nearshore & 0.25 & 0.00 & 0.25 \\
\hline California butterfly ray & Nearshore & 0.00 & 0.00 & 0.00 \\
\hline Banded guitarfish - DD & Nearshore & 0.00 & 0.00 & 0.00 \\
\hline Skate unid. & Unknown & 2511.36 & 8195.5 & 10706.855 \\
\hline Ray unid. & Unknown & 3.00 & 0.00 & 3.00 \\
\hline
\end{tabular}

(NT), and 1 shark species in the Vulnerable (VU) category (Tables $3 \& 4$; IUCN 2020). In addition, 6 shark, 2 skate, 1 ray, and 1 guitarfish species are considered Data Deficient (DD; Tables 3 \& 4; IUCN 2020). Some catch retention occurred in 12 species or species groups, most noticeably for all the oceanic sharks (3 EN), but also brown cat shark, the Pacific angel shark (NT), Pacific sleeper shark (DD), sandpaper skate 

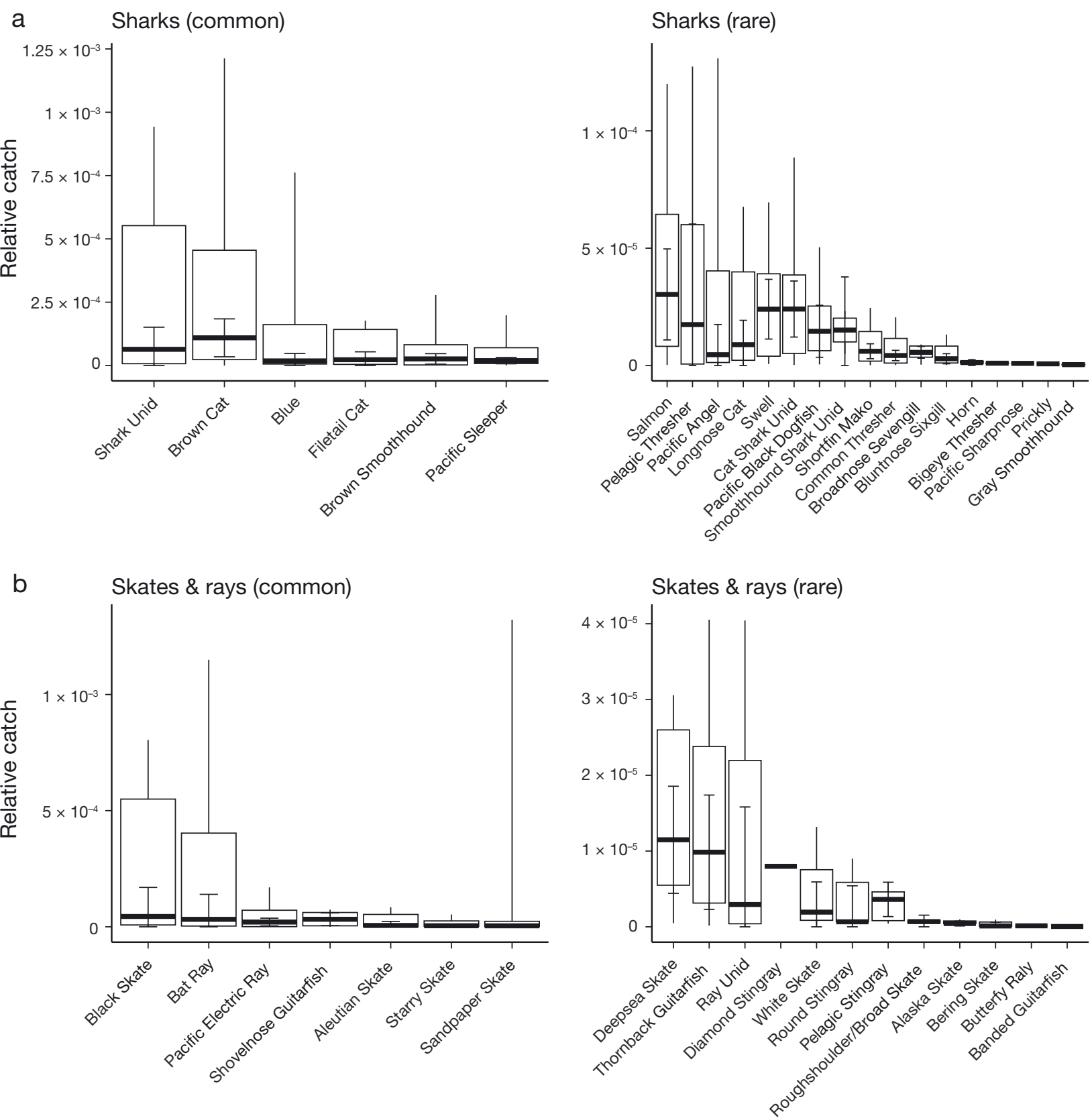

Fig. 1. Relative catch (bar: median; box: $\pm 25 \%$; top whisker: $90 \%$; error bar: $95 \%$ CI of median) of (a) sharks and (b) skates, rays, and guitarfish in US West Coast groundfish fisheries. Relative catch was calculated as the total catch of the elasmobranchs divided by the total landed catch. For clarity, elasmobranchs are divided into sharks and skates, and within each group, commonly caught species are plotted separately from rarely caught species. Unidentified skates are not shown

(DD), black skate, bat ray, and unidentified sharks and skates (Tables $3 \& 4$ ). Landed catch exceeded discards for bigeye thresher, common thresher, and shortfin mako sharks and unidentified skates. Indeed, the landed portion of the catch of unidentified skates was more than 3 times the at-sea discarded quantity by weight (Table 4 ), which was likely a reflection of different sorting requirements between the state- managed dock sampling programs and the NWGOP which strives for species-specific identification when possible. Fisheries targeting Pacific hake using pelagic midwater trawl nets (At-sea Catcher Processor, At-sea Mothership Catcher Vessels, and Shoreside Hake) normally dump the entire net contents directly into the hold and deliver without much at-sea sorting (except protected and prohibited species), which 
could account for retention of pelagic shark species. Overall, the total catch weight of VU or NT species was relatively low compared to other elasmobranch species (Tables $3 \& 4$ ). Excluding the 10 species or groups which had $\geq 50 \%$ of their total catch landed, $97 \%$ of the remaining total elasmobranch catch was discarded at sea during the study period (Tables 3 \& 4).

\subsection{Bycatch among sectors, ecomorphotypes, and time periods}

WCGF relative catch varied among sectors by ecomorphotype grouping (Tables 5, S2 \& S3, Fig. 2). The
LE Trawl-IFQ sector, which primarily uses bottom trawl nets near the continental shelf-slope break, had significantly larger catches of deep slope and slope sharks and deep sea and slope skates than all other sectors (Fig. 2, Table S3). The CA Halibut Trawl fishery, which primarily uses bottom trawl nets outside the mouth of San Francisco Bay, had significantly higher catches of nearshore skates and rays compared to other sectors and slightly higher catches of coastal sharks than other sectors (Fig. 2, Table S3). The LE Sablefish fleet, using fixed gear, had high catches of ocean sharks (exclusively on longline gear) relative to other sectors (Fig. 2, Table S3).

WCGF relative catch varied among sectors by period (Tables 5, S4 \& S5, Fig. 3). Among fishing sec-

Table 5. Generalized linear modeling results examining the effect of fishery sector (Table 1), ecomorphotype grouping (Table 1), and time period (2002-2006, 2007-2010, 2011-2014) on relative catch of elasmobranchs. Comparison of Akaike's information criterion among models and coefficients can be found in Tables S2 \& S3, respectively

\begin{tabular}{|c|c|c|c|c|c|c|}
\hline & $\mathrm{df}$ & Deviance & Residual df & Residual deviance & $F$ & $\mathrm{p}$ \\
\hline Null & & & 209 & $5.09 \times 10^{-7}$ & & \\
\hline Sector & 9 & $1.41 \times 10^{-7}$ & 200 & $3.69 \times 10^{-7}$ & 44.28 & $<0.0001$ \\
\hline Grouping & 6 & $2.38 \times 10^{-8}$ & 194 & $3.45 \times 10^{-7}$ & 11.23 & $<0.0001$ \\
\hline Time period & 2 & $1.84 \times 10^{-9}$ & 192 & $3.43 \times 10^{-6}$ & 2.61 & 0.08 \\
\hline Sector $\times$ grouping & 54 & $2.87 \times 10^{-7}$ & 138 & $5.56 \times 10^{-8}$ & 15.06 & $<0.0001$ \\
\hline Sector $\times$ time period & 18 & $1.32 \times 10^{-8}$ & 120 & $4.24 \times 10^{-8}$ & 2.08 & 0.01 \\
\hline
\end{tabular}

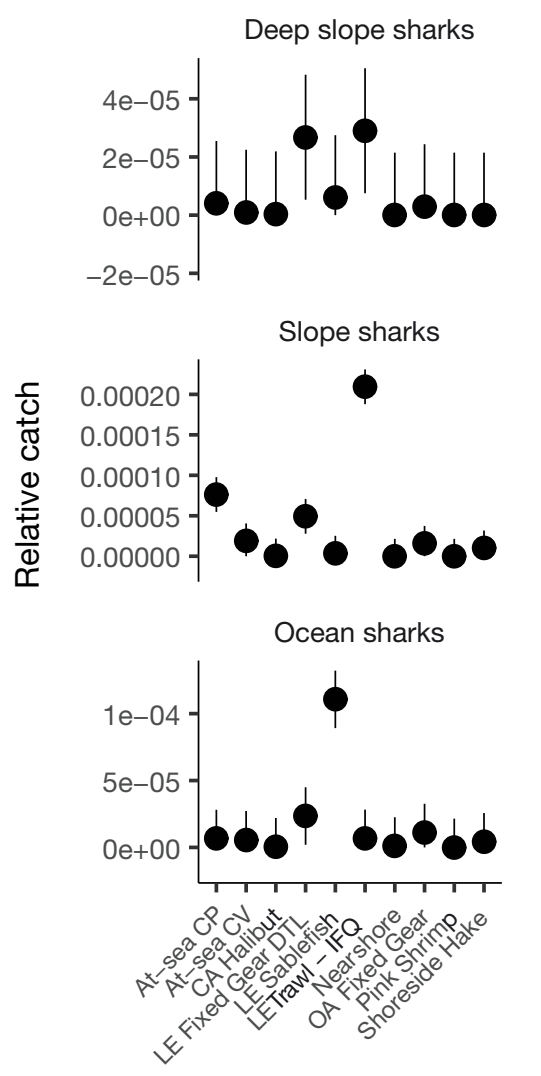

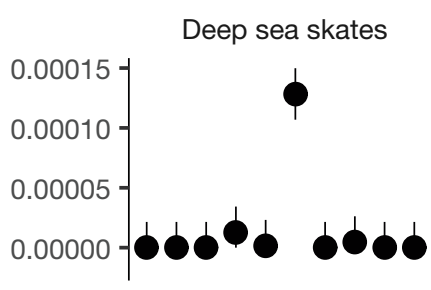

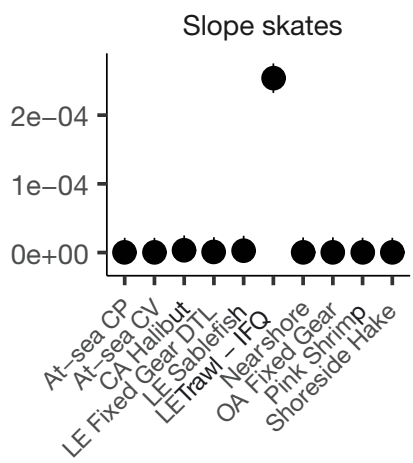

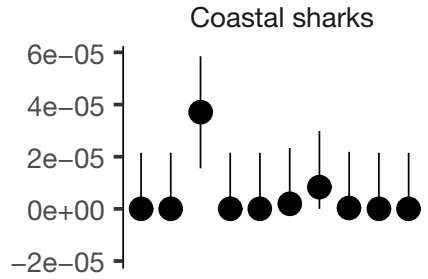

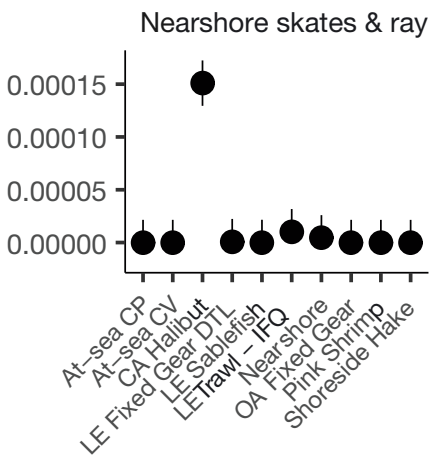

Fig. 2. Predicted relative catch $( \pm 95 \% \mathrm{CI})$ of elasmobranchs for each ecomorphotype (Table 1) and fishery sector in the US West Coast groundfish fisheries. Relative catch was calculated as the total catch of the elasmobranchs divided by the total landed catch. CP: catcher processor; CV: catcher vessel delivering to motherships; CA: California; LE: limited entry; DTL: daily trip limits; IFQ: individual fishing quota; OA: open access 

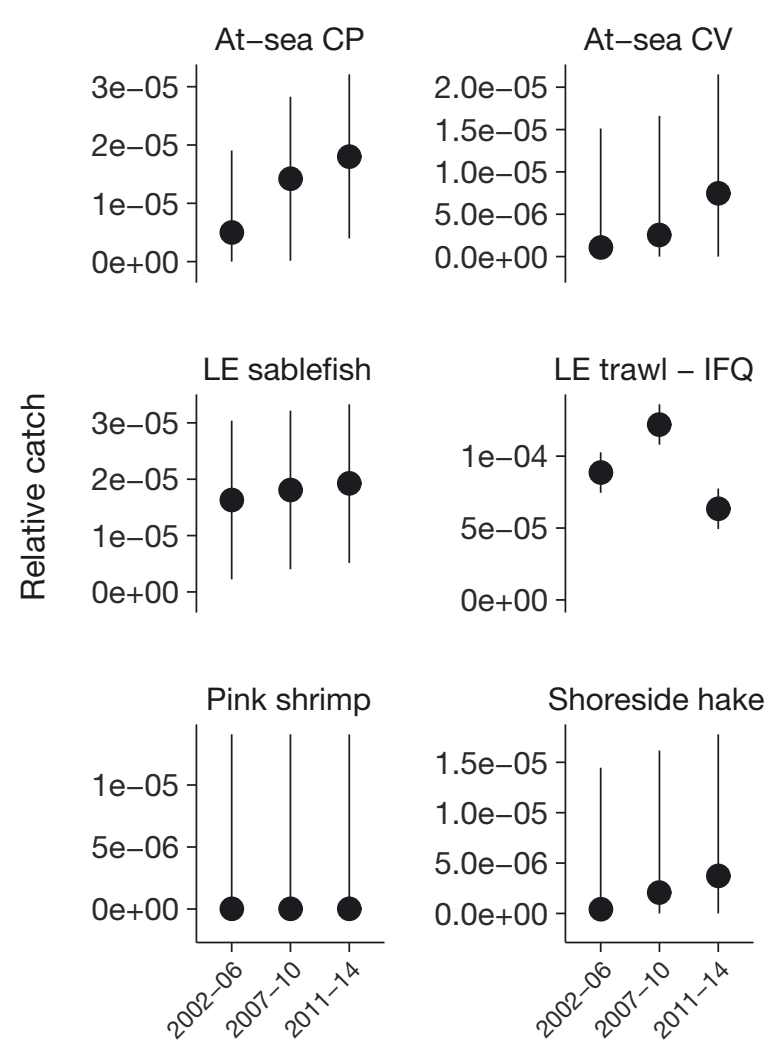

tors, the LE Trawl-IFQ sector exhibited an increase from 2002-2006 to 2007-2010 and then a significant drop in relative elasmobranch catch during the 20112014 period, coinciding with the implementation of the IFQ program (Fig. 3, Tables 5 \& S3). The CA Halibut sector showed a similar, but non-significant trend as the LE Trawl-IFQ sector. The hake sectors (At-sea Catcher-Processor, At-sea Catcher-Vessel, Shoreside Hake) and LE Fixed Gear DTL sector showed slight, but not significant, increases in elas-
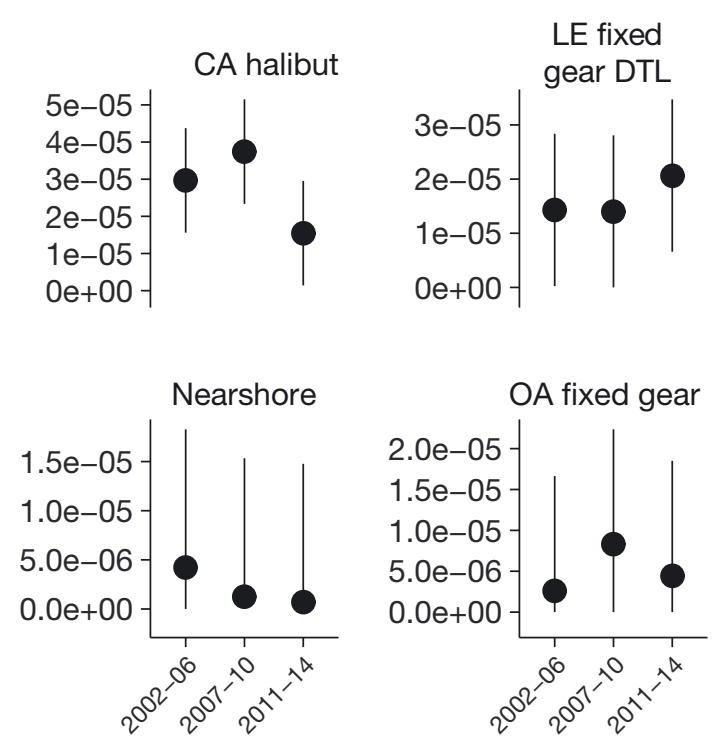

Fig. 3. Predicted relative catch $( \pm 95 \%$ CI) of elasmobranchs for each fishery sector in the US West Coast groundfish fisheries by time period. Relative catch was calculated as the total catch of the elasmobranchs divided by the total landed catch. See Fig. 2 for abbreviations

mobranch catch during the 2011-2014 period (Fig. 3). Other sectors did not exhibit significant patterns of elasmobranch catch over the 3 time periods (Fig. 3).

\subsection{Bycatch of IUCN species by fishing sector}

For IUCN-listed species within all 3 habitats, there were significant species by sector interactions (Tables 6 \& S4). In terms of oceanic sharks, the inter-

Table 6. Generalized linear modeling results examining the effect of species and sector on relative catch of IUCN-listed elasmobranchs (Table 4), which were grouped by habitat type and each habitat modeled separately. Comparison of Akaike's information criterion among models and coefficients can be found in Tables S4-S7

\begin{tabular}{|c|c|c|c|c|c|c|c|}
\hline Habitat & & df & Deviance & Residual df & Residual deviance & $F$ & $\mathrm{p}$ \\
\hline \multirow[t]{4}{*}{ Oceanic } & Null & & & 149 & $3.67 \times 10^{-4}$ & & \\
\hline & Species & 9 & $6.25 \times 10^{-5}$ & 140 & $3.05 \times 10^{-4}$ & 83.43 & $<0.0001$ \\
\hline & Sector & 4 & $4.99 \times 10^{-5}$ & 136 & $2.55 \times 10^{-4}$ & 149.83 & $<0.0001$ \\
\hline & Species $\times$ sector & 36 & $2.47 \times 10^{-4}$ & 100 & $8.32 \times 10^{-6}$ & 82.35 & $<0.0001$ \\
\hline \multirow[t]{4}{*}{ Slope } & Null & & & 167 & $2.01 \times 10^{-3}$ & & \\
\hline & Species & 7 & $2.89 \times 10^{-4}$ & 160 & $1.72 \times 10^{-3}$ & 19.77 & $<0.0001$ \\
\hline & Sector & 6 & $1.90 \times 10^{-4}$ & 154 & $1.53 \times 10^{-3}$ & 15.14 & $<0.0001$ \\
\hline & Species $\times$ sector & 42 & $1.30 \times 10^{-3}$ & 112 & $2.34 \times 10^{-4}$ & 14.78 & $<0.0001$ \\
\hline \multirow[t]{4}{*}{ Nearshore } & Null & & & 104 & $6.27 \times 10^{-6}$ & & \\
\hline & Species & 4 & $8.85 \times 10^{-7}$ & 100 & $5.39 \times 10^{-6}$ & 5.84 & 0.0004 \\
\hline & Sector & 6 & $5.86 \times 10^{-7}$ & 94 & $4.80 \times 10^{-6}$ & 2.58 & 0.03 \\
\hline & Species $\times$ sector & 24 & $2.15 \times 10^{-6}$ & 70 & $2.65 \times 10^{-6}$ & 2.37 & 0.003 \\
\hline
\end{tabular}


action was driven by the fixed gear fleets (LE Sablefish, LE Fixed Gear DTL, OA Fixed Gear), which caught significantly more blue sharks than other sectors (Fig. 4 Table S5). These sectors fish with various hook-and-line or pot/trap gear in federally managed waters $(5.6 \mathrm{~km}$ offshore). Blue sharks were exclusively caught on hook-and-line gear. For slope species, the interaction was driven by significantly higher catches of sandpaper skates in the LE Trawl-IFQ sector and slightly higher, but not significant, catches of Pacific sleeper shark in both the LE Trawl-IFQ and LE Fixed Gear DTL relative to other sectors (Fig. 5, Table S6). Nearshore species interactions were driven by significantly higher catches of Pacific angel sharks and shovelnose guitarfish in the CA Halibut fishery (Fig. 6, Table S7).

\subsection{Elasmobranch catch and IFQ implementation}

Within the LE bottom trawl-IFQ sector, for taxa identified to species level, there was a significant 3way interaction between species, catch disposition, and time period (Table 7), suggesting that at-sea discards and landed at the dock differed among species and time periods in different ways. Brown cat and Pacific sleeper sharks as well as black and sandpaper skates appeared to have significantly more at-sea discards than landed at the dock (Fig. 7). At-sea discards for brown cat shark, black skate, and sandpaper skate appeared to be significantly lower during the 2002-2006 and 2011-2014 (IFQ) periods, peaking in 2007-2010 (Fig. 7, Table S8). Pacific sleeper shark at-sea discards increased from 2002-2006 to 2007-2010, peaking during the IFQ period (20112014) (Fig. 7, Table S8). Brown cat shark landings at the dock appeared to be up slightly in the 20112014 period compared to 2002-2006 and 2007-2010, whereas landings of the 2 skate species followed the pattern for at-sea discards: lower landings in 20022006, a peak in 2007-2010, and a drop in landings in 2011-2014 (Fig. 7, Table S8).

\section{DISCUSSION}

We present the first analysis of non-managed elasmobranch bycatch in the US WCGF. The North Pacific region is identified as an area with substantial gaps in elasmobranch catch and discard estimates (Oliver et al. 2015), and this study helps fill this gap. Our work highlights several important points for management consideration. First, there are species of conservation concern that appear in the catch of
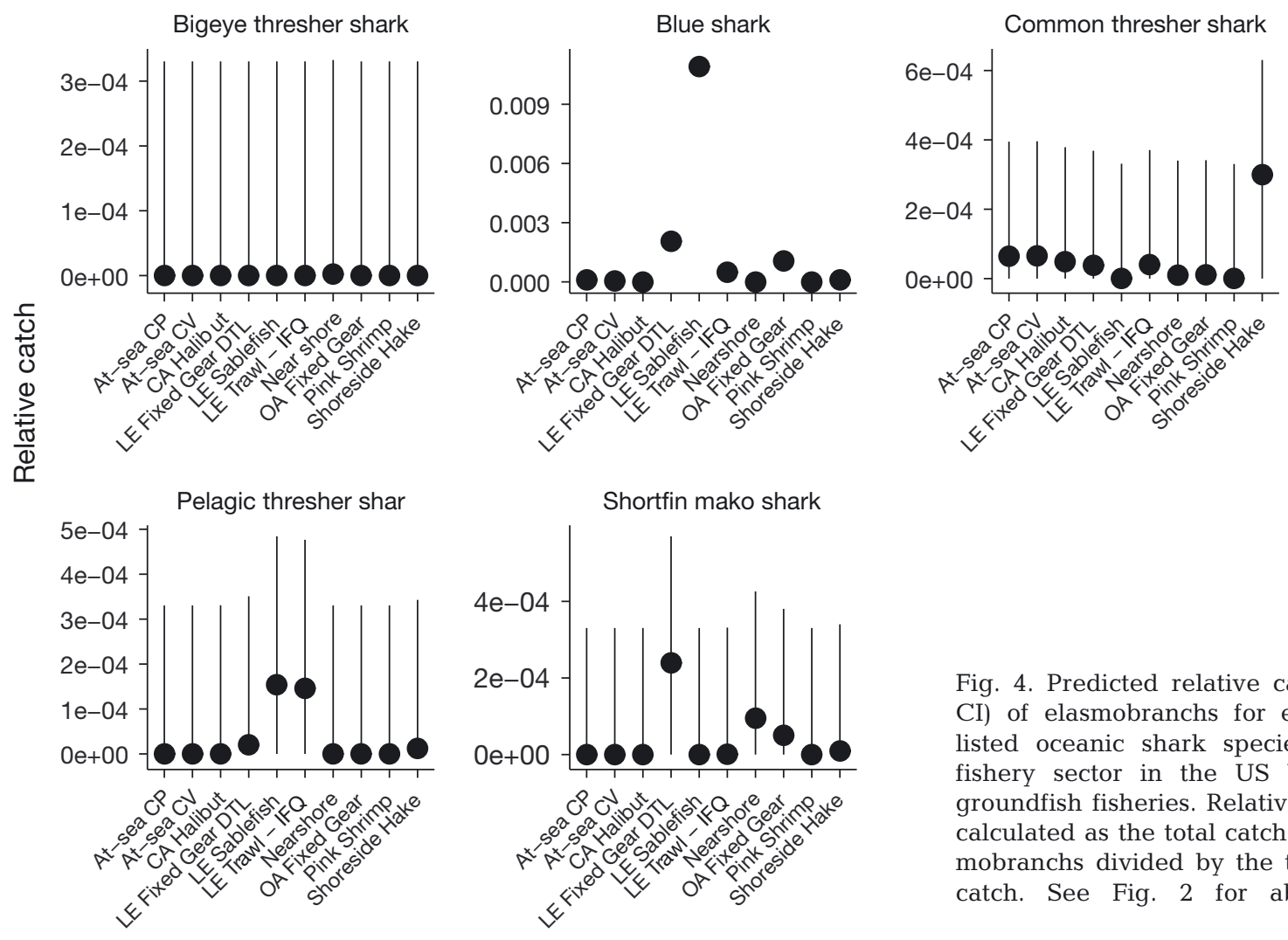

Fig. 4. Predicted relative catch $( \pm 95 \%$ CI) of elasmobranchs for each IUCNlisted oceanic shark species for each fishery sector in the US West Coast groundfish fisheries. Relative catch was calculated as the total catch of the elasmobranchs divided by the total landed catch. See Fig. 2 for abbreviations 

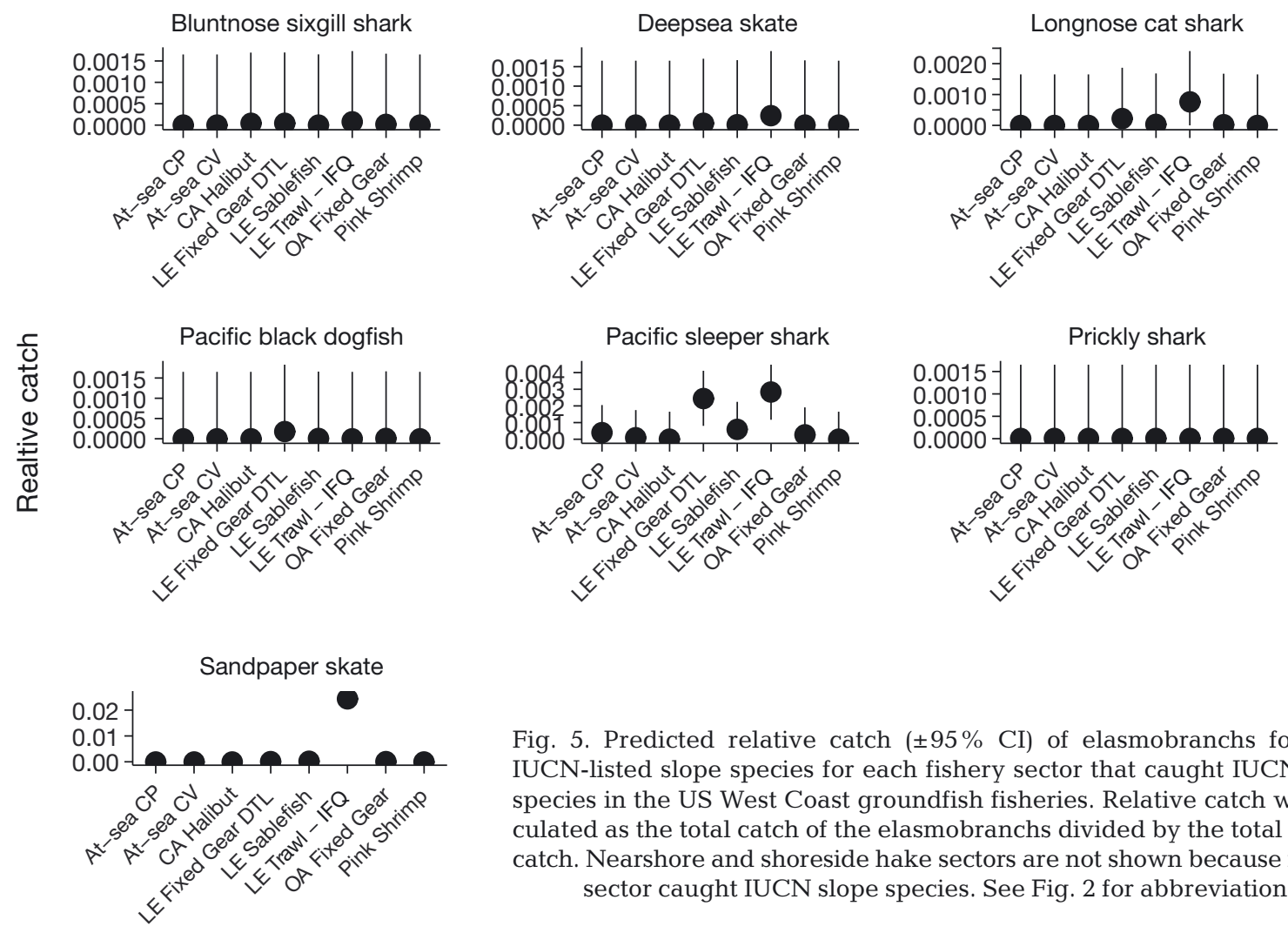

Fig. 5. Predicted relative catch $( \pm 95 \%$ CI) of elasmobranchs for each IUCN-listed slope species for each fishery sector that caught IUCN slope species in the US West Coast groundfish fisheries. Relative catch was calculated as the total catch of the elasmobranchs divided by the total landed catch. Nearshore and shoreside hake sectors are not shown because neither sector caught IUCN slope species. See Fig. 2 for abbreviations
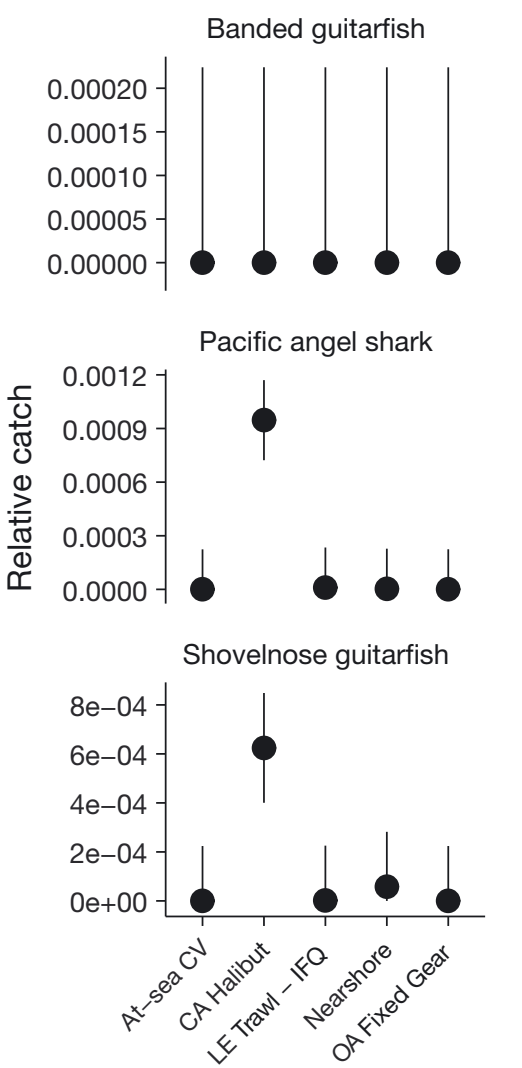

Diamond stingray

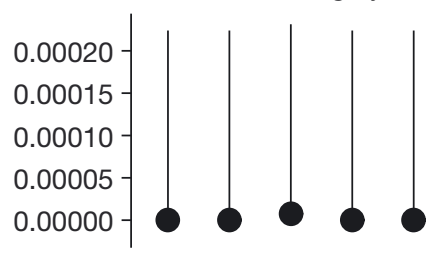

Pacific sharpnose shark

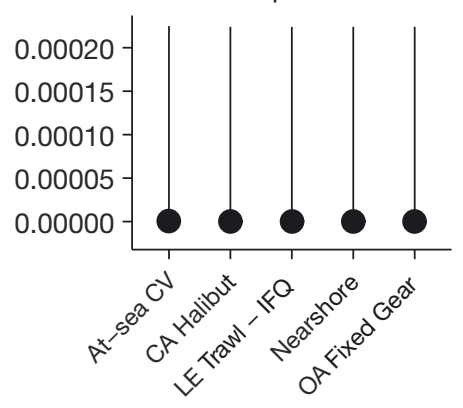

Horn shark
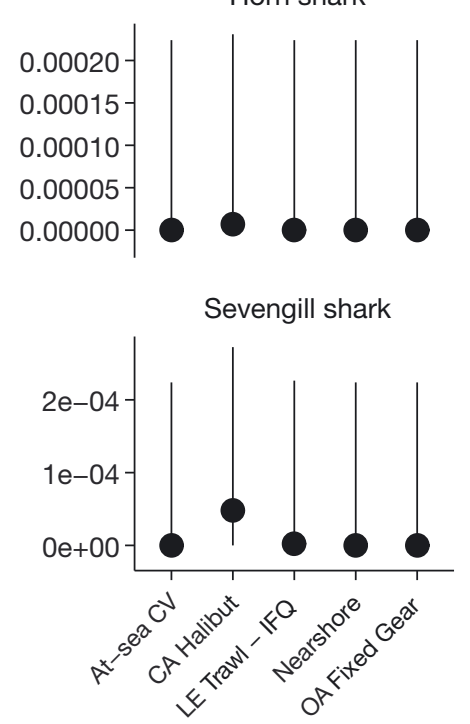

Fig. 6. Predicted relative catch $( \pm 95 \% \mathrm{CI})$ of elasmobranchs for each IUCN-listed nearshore species for each fishery sector that caught IUCN listed nearshore species in the US West Coast groundfish fisheries. Relative catch was calculated as the total catch of the elasmobranchs divided by the total landed catch. At-sea Catcher Processor, LE Fixed Gear Daily Trip Limits, LE Sablefish, Pink Shrimp and Shoreside Hake sectors are not shown because they did not catch IUCN-listed nearshore species. See

Fig. 2 for abbreviations 
Table 7. Generalized linear modeling results examining the effect of species, catch disposition (at-sea discard, landed at dock), and time period (2002-2006, 2007-2010, 2011-2014) on catch weight (mt) in the Limited Entry Trawl-Individual Fishing Quota (LE Trawl-IFQ) sector. Coefficients from these models are presented in Table S8

\begin{tabular}{|c|c|c|c|c|c|c|}
\hline & df & Deviance & Residual df & Residual deviance & $F$ & $\mathrm{p}$ \\
\hline Null & & & 779 & 87204 & & \\
\hline Species & 29 & 35228 & 750 & 51976 & 111.82 & $<0.0001$ \\
\hline Catch disposition & 1 & 4844 & 749 & 47132 & 445.88 & $<0.0001$ \\
\hline Time period & 2 & 167 & 747 & 46964 & 7.70 & $<0.0001$ \\
\hline Species $\times$ catch disposition & 29 & 35101 & 718 & 11863 & 111.42 & $<0.0001$ \\
\hline Species $\times$ time period & 58 & 2595 & 660 & 9269 & 4.12 & $<0.0001$ \\
\hline Catch disposition $\times$ time period & 2 & 166 & 658 & 9103 & 7.62 & $<0.0001$ \\
\hline Species $\times$ catch disposition $\times$ time period & 58 & 2585 & 600 & 6518 & 4.10 & $<0.0001$ \\
\hline
\end{tabular}

groundfish fisheries on the US West Coast. However, most of these species of concern rarely appear in the catch, and when they are present, they appear in relatively small amounts compared to other fisheries along the US West Coast (e.g. pelagic drift gillnet fishery). Relative catch of non-managed elasmobranchs in WCGF trawl fisheries are closer to the lower end of global averages (Oliver et al. 2015). Second, a large proportion of both shark and skate catches is unidentified, in particular landed catch, limiting the ability of managers to understand the risks to specific species. Third, our work indicates that suites of elasmobranch species with similar eco- logical requirements might be able to be managed en masse. Ecomorphotypes are area- and depth-specific and appear to be strongly associated with specific fishing grounds and gear types, potentially simplifying management for large groups of non-target species under an ecosystem-based management approach. Fourth, our work suggests that even when species are excluded from explicit fisheries management programs, implementing or changing management strategies could have impacts on unmanaged species. Below, we discuss each of these ideas indepth and conclude with suggestions for improving elasmobranch bycatch management.
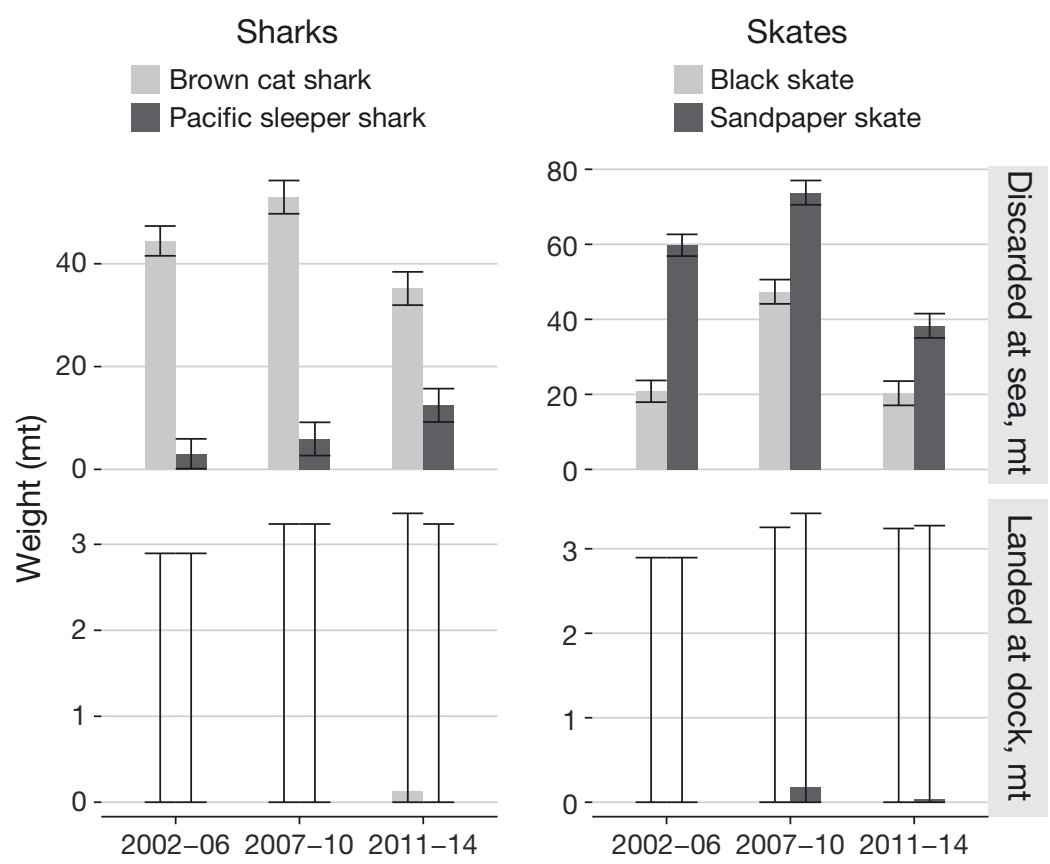

Fig. 7. Predicted weight $( \pm 95 \%$ CI) of brown cat and Pacific sleeper sharks, black and sandpaper skates in the LE Trawl-IFQ fishery by catch disposition (at-sea discard [upper], landed at dock [lower]) and time period (2002-2006, 2007-2010, 2011-2014)

\subsection{Managing species of concern}

We identified a suite of elasmobranchs that are of global concern and are caught by these fisheries in relatively low amounts. Nine species found in groundfish catches are currently listed as EN, VU or NT with declining or unknown population trends and 10 species are considered DD (IUCN 2020). Seven of the EN, VU or NT shark species are being landed in small amounts in these fisheries, mainly shortfin mako, common thresher, and Pacific angel shark. A recent stock assessment of shortfin mako sharks over a $42 \mathrm{yr}$ period concluded that it is not likely overfished in the North Pacific (ISC Shark Working Group 2018). However, Rigby et al. (2019b) extended this analysis over 72 yr ( 3 generations). Under this scenario, rates of decline of the North Pacific shortfin mako population could be as much as 
30-49\% (Rigby et al. 2019b). Common thresher shark in the Eastern North Pacific also do not appear to be overfished (Teo et al. 2018), but some caution is warranted as this assessment is based largely on data from fishery catches. Other common thresher shark populations do appear to be in decline (Rigby et al. 2019a). Even though the amount of landed catch of these species in the WCGF is relatively low compared to unlisted species, our work fills gaps in reporting (Oliver et al. 2015, Rigby et al. 2019 a,b) and provides baseline data for management of these species on the US West Coast. For example, there is evidence that the commercial fishery for Pacific angel shark in California has been increasing landings in recent years (CDFW 2020). In addition, a number of elasmobranch species, while not yet meriting categorization as Threatened or Endangered, do have restricted ranges and low reproductive potential (e.g. several batoids, coastal shark species), making them vulnerable to overfishing. Closer scrutiny of these species by fisheries managers that could reap ecosystem benefits (Crowder et al. 2008, Ritchie \& Johnson 2009, Polovina \& Woodworth-Jefcoats 2013).

Closer scrutiny requires better identification requirements for landed non-managed elasmobranchs. Approximately $25 \%$ of sharks and $99 \%$ of skates in the landed catch were grouped into broad unidentified categories (e.g. sharks unidentified, etc.) because there is no dockside sorting and identification requirements for unmanaged elasmobranch species (PFMC 2019). At-sea observers are required to sort and identify all discarded species to the lowest taxonomic unit possible, including elasmobranchs. Unidentified elasmobranch landings limit our capacity to (1) understand the risks to sensitive elasmobranch species and (2) manage or mitigate those risks. Dockside sorting and identification requirements for landed elasmobranchs would improve our understanding of fishing impacts on these species.

\subsection{Ecomorphotypes as a management unit}

Our work on ecomorphotype groupings suggests that even regulations targeted at single elasmobranch species could yield benefits for other species of the same ecomorphotype and thereby potentially amplify the benefits of single-species management across multiple species. Ecomorphotypes encompass a number of species that share general habitat characteristics (e.g. depth, area; Table 1). There is a strong relationship between the ecomorphotypes caught by a fishery sector and the general geographic area where that sector typically fishes as exemplified in Fig. 2, which shows slope fisheries (e.g. LE TrawlIFQ) tend to catch slope species, oceanic hook-andline fisheries (e.g. LE Sablefish) tend to catch ocean sharks, and coastal fisheries (e.g. CA Halibut) catch nearshore species. This opens an opportunity for managers-managing a gear type, even if for the purposes of a single elasmobranch species, could in effect lead to an EBFM approach with maximum effect because multiple sectors with similar gear types (e.g. hook-and-line) have a similar impact on all the species within an ecomorphotype grouping. For example, the California Halibut Bottom Trawl sector fishes relatively close to shore $(<5.6 \mathrm{~km}$ offshore) in relatively shallow waters (generally $<200$ $\mathrm{m}$ ) and consequently catches a higher proportion of coastal sharks and nearshore skates and rays than other US West Coast fisheries (Fig. 2), suggesting that management of this sector could benefit nearshore ecomorphotypes. Furthermore, there are other fishery sectors that fish in the nearshore (Pink Shrimp, Nearshore Fixed Gear), and thus management of these ecomorphotypes could reap benefits across fisheries. Similar cross-sector impacts could be achieved by managing oceanic sharks in fixed gear fisheries and slope elasmobranchs in off-shore trawl fisheries. The relationship between ecomorphotypes and sectors or gear means that simple single-species management is likely to have impacts on the wider group of ecomorphotypes and therefore bringing management goals in closer alignment with EBFM. Future work should be directed toward a more objective characterization of ecomorphotypes, especially for skates and rays.

\subsection{Management impacts on unmanaged species}

Our data suggest that at least some unmanaged elasmobranchs might have benefited from the implementation of the IFQ program. The shift was encouraging across all species: elasmobranch catch was initially on the rise from the 2002-2006 to the 2007-2010 period and then at-sea discard dropped by about $36 \%$ and landings at the dock dropped by about $44 \%$ from the pre-IFQ period (2007-2010) to the IFQ period (2011-2014), similar to levels seen in the 2002-2006 period. Three elasmobranch species (1 shark and 2 skates) showed a significant drop in both at-sea discards and landings at the dock during the 2011-2014 period compared to the past. Furthermore, we detected little change in catch of the remaining 27 elasmobranch species caught by the LE-IFQ 
bottom trawl fleet. Thus, our study finds some support for the idea that an IFQ program can have indirect positive effects - or at minimum, no negative effects - on non-managed species. There is no a priori reason to believe that all unmanaged species will respond positively to an IFQ program (but see Somers et al. 2018b), or any change in management. For example, it is completely plausible that in some cases, a limited IFQ program like the one implemented in the WCGF might incentivize landings of species that are outside the IFQ requirements. In such cases we might expect negative impacts of an IFQ program on unmanaged species, for example, if fishers try to capitalize on unexplored or underutilized markets with unmanaged species. However, exploiting new or under-utilized species would require investment in market research and testing, which could be expensive and risky. We found no evidence for the idea that fishers began retaining non-managed elasmobranchs. The IFQ program appears to incentivize fishing effort to maximize catch of the valuable IFQ species while avoiding unwanted species. However, it should be noted that there are other explanations for the patterns we observed; most notably, changes in species distribution and/or abundance, which might also contribute to the drop in catch during the 2011-2014 period.

This work is an example of how fisheries management for a subset of the ecosystem has implications for species outside the formal management framework. Initiating new or significant changes to management has the potential to tip the balance between discards at sea and landings of non-managed species as fishers seek new markets with less regulatory oversight. The accuracy of elasmobranch stock assessments, IUCN classifications, fishery management plans, and other reporting forums would benefit from ensuring that WCGF elasmobranch bycatch are included in these management platforms and help reduce the risk of overexploitation of these species (Worm et al. 2013).

\subsection{Conclusions and future work}

This study emphasized how fisheries management changes might affect unmanaged elasmobranchs and provided some simple solutions for more formal management of these species. One area in need of collaborative work are species of concern that appear in both US West Coast groundfish and HMS fisheries; for example, oceanic sharks. The PFMC manages both the WCGFMP and the HMS FMP. Assess- ing the total fishing effects on these species and developing an appropriate management strategy will require synthesis and analyses across groundfish and HMS management plans, as is discussed in the WCGFMP (PFMC 2019). In addition, improved management to avoid overexploitation of elasmobranchs is going to require better taxonomic resolution. Dockside sorting requirements for landed elasmobranch species, at the finest taxonomic resolution possible, is one simple step toward better management of these species. Furthermore, the use of ecomorphotypes, which encompass a suite of species that are area- and depth-specific, has the potential to streamline management in an EBFM approach. More precise and objective definitions of elasmobranch ecomorphotypes, especially for skates and rays, will provide a useful tool for managers. Finally, close monitoring of shifting target groups and markets after implementing or changing management strategies will help managers stay ahead of any potential unintended consequences for non-managed species.

Acknowledgements. We thank all of the fisheries observers and shoreside samplers who collected the valuable data necessary for this project. We thank Y. W. Lee, C. Russell, and 3 anonymous reviewers for valuable suggestions that improved earlier versions of the manuscript. R.B. acknowledges the support of the National Research Council Research Associateship Program and M. McClure.

\section{LITERATURE CITED}

Alverson DL, Freeberg MH, Murawski SA, Pope JG (1994) A global assessment of fisheries bycatch and discards. FAO Fisheries Technical Paper No. 339. FAO, Rome

Baum JK, Worm B (2009) Cascading top-down effects of changing oceanic predator abundances. J Anim Ecol 78: 699-714

Bellman MA, Al-Humaidhi AW, Jannot J, Majewski J (2011) Estimated discard and catch of groundfish species in the 2010 US West Coast fisheries. Fisheries Observation Science Program NWFSC. NOAA Fisheries, Seattle, WA

Block BA, Jonsen ID, Jorgensen SJ, Winship AJ and others (2011) Tracking apex marine predator movements in a dynamic ocean. Nature 475:86-90

*Banch TA (2009) How do individual transferable quotas affect marine ecosystems? Fish Fish 10:39-57

* CDFW (California Department of Fish and Wildlife) (2020) Final California commercial landings. https://wildlife. ca.gov/Fishing/Commercial/Landings (accessed April 2020)

Clarke SC, McAllister MK, Milner-Gulland EJ, Kirkwood GP and others (2006) Global estimates of shark catches using trade records from commercial markets. Ecol Lett 9:1115-1126

Compagno LJV (1990) Shark exploitation and conservation. In: Pratt HL Jr, Gruber SH, Taniuchi T (eds) Elasmobranchs as living resources: advances in the biology, 
ecology, systematics, and the status of fisheries: proceedings of the $2^{\text {nd }}$ United States-Japan Workshop, Book 90. NOAA National Marine Fisheries Service, East-West Center, Honolulu, HI, p 391-414

Cortés E (2002) Incorporating uncertainty into demographic modeling: application to shark populations and their conservation. Conserv Biol 16:1048-1062

* Crowder LB, Hazen EL, Avissar N, Bjorkland R, Latanich C, Ogburn MB (2008) The impacts of fisheries on marine ecosystems and the transition to ecosystem-based management. Annu Rev Ecol Evol Syst 39:259-278

Davies RWD, Cripps SJ, Nickson A, Porter G (2009) Defining and estimating global marine fisheries bycatch. Mar Policy 33:661-672

* Dayton PK, Thrush SF, Agardy MT, Hofman RJ (1995) Environmental effects of marine fishing. Aquat Conserv 5: 205-232

Dulvy NK, Fowler SL, Musick JA, Cavanagh RD and others (2014) Extinction risk and conservation of the world's sharks and rays. eLife 3:e00590

Fong QSW, Anderson JL (2002) International shark fin markets and shark management: an integrated market preference-cohort analysis of the blacktip shark (Carcharhinus limbatus). Ecol Econ 40:117-130

Fowler SL, Cavanagh RD, Camhi M, Burgess GH and others (2005) Sharks, rays and chimaeras: the status of the chondrichthyan fishes. IUCN/SSC Shark Specialist Group, Gland

Fox J (2003) Effect displays in R for generalised linear models. J Stat Softw 8:1-27

Fox J, Weisberg S (2018) Visualizing fit and lack of fit in complex regression models with predictor effect plots and partial residuals. J Stat Softw 87:1-27

Fox J, Weisberg S (2019) An R companion to applied regression, $3^{\text {rd }}$ edn. https://socialsciences.mcmaster.ca/jfox/ Books/Companion/index.html

ISC Shark Working Group (2018) Annex 15: stock assessment of shortfin mako shark in the North Pacific Ocean through 2016. Report of The Shark Working Group at the $18^{\text {th }}$ meeting of the International Scientific Committee for Tuna and Tuna-like Species in the North Pacific Ocean, Yeosu, Republic of Korea, 11-16 July 2018

IUCN (2020) The IUCN Red List of Threatened Species, version 2020-2. https://www.iucnredlist.org/

James KC, Lewison RL, Dillingham PW, Curtis KA, Moore JE (2016) Drivers of retention and discards of elasmobranch non-target catch. Environ Conserv 43:3-12

Kelleher K (2005) Discards in the world's marine fisheries: an update. FAO Fisheries Technical Paper No. 470. FAO, Rome

Latour RJ, Brush MJ, Bonzek CF (2003) Toward ecosystembased fisheries management. Fisheries 28:10-22

Link JS (2002) What does ecosystem-based fisheries management mean? Fisheries (Bethesda, Md) 27:18-21

Link JS (2010) Ecosystem-based fisheries management confronting tradeoffs. Cambridge University Press, Cambridge

Melnychuk MC, Essington TE, Branch TA, Heppell SS and others (2012) Can catch share fisheries better track management targets? Fish Fish 13:267-290

*Martin RA (2010) Shark ecomorphotypes. www.elasmoresearch.org/education/topics/de_ecomorphotypes.htm

NMFS (National Marine Fisheries Service) (2010) Compliance guide for the Pacific coast groundfish trawl rationalization program. NMFS, NOAA, US Dept Commerce
NWFSC (Northwest Fisheries Science Center) (2016a) Atsea Hake Observer Program observer sampling manual. Fisheries Observation Science program NWFSC. NOAA Fisheries, Seattle, WA

NWFSC (2016b) West Coast Groundfish Observer Program 2016 catch shares training manual. Fisheries Observation Science Program NWFSC. NOAA Fisheries, Seattle, WA

NWFSC (2016c) West Coast Groundfish Observer Program 2016 non-catch shares training manual. Fisheries Observation Science Program NWFSC. NOAA Fisheries, Seattle, WA

NWFSC (2020a) Fisheries observers: West Coast Groundfish Observer Program data processing. https://www. fisheries.noaa.gov/west-coast/fisheries-observers/westcoast-groundfish-observer-program-data-processing

NWWSC (2020b) Fisheries observers: West Coast Groundfish and At-Sea Hake observer data collection, quality control, training, and sampling manuals. https://www.fisheries. noaa.gov/west-coast/fisheries-observers/west-coastgroundfish-and-sea-hake-observer-data-collection-quality

Oliver S, Braccini M, Newman SJ, Harvey ES (2015) Global patterns in the bycatch of sharks and rays. Mar Policy 54:86-97

*PFMC (Pacific Fishery Management Council) (2019) Pacific Coast Groundfish Fishery Management Plan for the California, Oregon, and Washington groundfish fishery. https://www.pcouncil.org/documents/2016/08/pacificcoast-groundfish-fishery-management-plan.pdf

* Polovina JJ, Woodworth-Jefcoats PA (2013) Fishery-induced changes in the subtropical Pacific pelagic ecosystem size structure: observations and theory. PLOS ONE 8:e62341

R Core Team (2019) R: a language and environment for statistical computing. R Foundation for Statistical Computing, Vienna

* Rigby CL, Barreto R, Fernando D, Carlson J and others (2019a) Alopias vulpinus. The IUCN Red List of Threatened Species 2019:e.T39339A2900765. https://dx.doi. org/10.2305/IUCN.UK.2019-3.RLTS.T39339A2900765.en (accessed 2 December 2020)

* Rigby CL, Barreto R, Carlson J, Fernando D and others (2019b) Isurus oxyrinchus. The IUCN Red List of Threatened Species 2019:e.T39341A2903170. https://dx.doi.org/ 10.2305/IUCN.UK.2019-1.RLTS.T39341A2903170.en (accessed 2 December 2020)

Ritchie EG, Johnson CN (2009) Predator interactions, mesopredator release and biodiversity conservation. Ecol Lett 12:982-998

Somers KA, Jannot JE, Lee YW, Riley NB, Tuttle V, McVeigh J (2015) Estimated discard and catch of groundfish species in the 2014 US West Coast fisheries. Fisheries Observation Science Program NWFSC. NOAA Fisheries, Seattle, WA

Somers KA, Jannot JE, Richerson K, Tuttle V, McVeigh J (2018a) FOS coverage rates, 2002-2018. Fisheries Observation Science Program NWFSC. NOAA Fisheries, Seattle, WA

Somers KA, Pfeiffer L, Miller S, Morrison W (2018b) Using incentives to reduce bycatch and discarding: results under the West Coast Catch Share Program. Coast Manage 46: 621-637

Stevens JD, Bonfil R, Dulvy NK, Walker PA (2000) The effects of fishing on sharks, rays, and chimaeras (chondrichthyans), and the implications for marine ecosystems. ICES J Mar Sci 57:476-494 
Teo S, Garcia Rodriguez E, Sosa-Nishizaki O (2018) Status of common thresher sharks, Alopias vulpinus, along the West Coast of North America: updated stock assessment based on alternative life history. NOAA Tech Memo NMFS-SWFSC-595.

Walker TI (1998) Can shark resources be harvested sustainably? A question revisited with a review, of shark fisheries.

Editorial responsibility: Richard Reina,

Clayton, Victoria, Australia

Reviewed by: 3 anonymous referees
Mar Freshw Res 49:553-572

* Ward-Paige CA, Keith DM, Worm B, Lotze HK (2012) Recovery potential and conservation options for elasmobranchs. J Fish Biol 80:1844-1869

* Worm B, Davis B, Kettemer L, Ward-Paige CA and others (2013) Global catches, exploitation rates, and rebuilding options for sharks. Mar Policy 40:194-204

Submitted: September 17, 2020

Accepted: February 25, 2021

Proofs received from author(s): May 27, 2021 